\title{
POLYCENTRIC INTRA-URBAN DEVELOPMENT OF HOTELS: EVIDENCE FROM BUDAPEST
}

\author{
Tomasz Napierała ${ }^{1,2}$ \\ ${ }^{1}$ Faculty of Geographical Sciences \\ University of Łódź \\ Kopcińskiego 31, 90-142 Łódź: Poland \\ e-mail: tomasz.napierala@geo.uni.lodz.pl \\ ${ }^{2}$ CiTUR, Centre for Tourism \\ Research Development and Innovation \\ 2520-641 Peniche, Santuário de Nossa Senhora dos Remédios: Portugal
}

\begin{abstract}
The aim of the paper is to understand evolutionary changes of hotel intra-urban location policy during the period of the economic transition. Thus, the theoretical model of polycentric intra-urban development of hotel facilities is introduced in this research. Polycentric development is defined as the result of two ongoing and contrary tendencies: (1) spatial sprawl of hotel facilities resulting from new hotel investments, and (2) concentration of hotel enterprises, which is the effect of demand-based and production-based agglomeration processes of hotel facilities in particular locations. To examine this theoretical concept, the changes of spatial distribution of hotel entities in Budapest since 1982 were investigated. Kernel density estimation was applied to identify the number, location, and area of clusters of hotel services. Empirical evidence confirms the proposed theoretical model of polycentric intra-urban development of hotels, although significant hotel clusters are only formed in the central districts of Budapest.
\end{abstract}

\section{Key words}

hotels $\bullet$ polycentricity $\bullet$ city $\bullet$ Budapest $・$ evolutionary economic geography

\section{Introduction}

Understanding how hotels change their location policy in intra-urban context might be interesting from scientific and practical (for both lodging industry and city planning) points of view. The decision concerning hotel location is one of the most challenging elements of hotel strategic planning. The decision is significantly complex, as it is influenced by various determinants: environmental, economic, geographic, and socio-cultural. Moreover, the choice of a location is the process that has to take into account not only the current situation, but also future changes of determinants of hotel performance, both 
short- and long-term (Adam \& Amuquandoh 2013, 2014; Luo \& Yang 2016). Understanding hotel development patterns in a city allows to provide a cohesion of economic effectiveness of hotel enterprises, sustainability of spatial planning, and efficiency of urban destination management strategy (Adam \& Amuquandoh 2014; Li, Fang, Huang, \& Goh 2015).

There is a multitude of studies on hotel location selection. However, there is a still research niche in the investigation of spatial agglomeration's impact on hotel location decisions (Adam \& Mensah 2013). The aim of the paper is to understand evolutionary changes of hotel intra-urban location policy. Hence, the changes of the intra-urban location of hotel clusters need to be investigated. The theoretical model of polycentric intraurban development of hotel facilities is introduced in this article. It is derived from the existing theoretical, empirical, and operational concepts of polycentricity in general, and concepts of intra-urban hotel agglomeration effects, and location of hotel clusters in details. Then, introduced theoretical model is evidenced by the case study of the hotel industry development in the city of Budapest. Theory and evidence presented in this study might be considered as a contribution to the scientific discipline which Ashworth \& Page (2011) called "urban geography of tourism".

This paper is organised as follows. First, the theory is presented. Polycentricity of urban structures is discussed in general. Then, the idea of clustering urban hotel services is introduced. Moreover, findings from studies on intra-urban locations of hotel agglomerations, including determinants of spatial distribution of hotel clusters, are presented. Secondly, the history of development of hotel services during the whole period of economic transition in the investigated area, namely the city of Budapest, is discussed. Thirdly, the methodological framework is elaborated upon, consisting of two parts: data collection and the method of empirical data analysis. Fourthly, results are presented. And finally, empirical findings are confronted with results from other authors. Then, conclusions are delivered.

\section{Theoretical framework \\ Polycentricity of urban structures}

Evidence shows, that urban areas are becoming more and more decentralised. They are evolving from monocentric to dispersed or polycentric structures. Urban life concentrated in a city centre becomes clustered in subcentres (Anas, Arnott, \& Small 1998; Yue, Liu, \& Fan 2010). The creation of such subcentres results from the tension between two forces in a city: agglomerative and dispersive. When too many activities are collocated, dispersive processes occur and finally subcentres might form (Anas et al. 1998). Two different types of polycentricity should be emphasised: morphological and functional. The morphological context refers to the spatial distribution of investigated activities, while the functional context is focused on interactions and relations (Veneri \& Burgalassi 2012). In this study, the only considered type of polycentricity is the morphological one. However, results of the enquiry by Veneri \& Burgalassi (2012) confirmed, that no substantial differences between the two approaches occur when measuring polycentricity.

Polycentricity might be defined at different geographical scales (Burger, van der Knaap, \& Wall 2014; Parr 2004; Veneri \& Burgalassi 2012; Yue et al. 2010). At international, national or regional level, polycentricity allows to describe networks of cities - polycentric urban regions. At urban level, polycentricity refers to localities of the city or metropolitan area. Polycentricity also has an influential political and economic context, as a polycentric development policy supports more balanced spatial development (Burger et al. 2014) and enables spatial justice (Dabinett \& Richardson 2005). Therefore, economic growth is more equally distributed, while the negative effects of competition are reduced. Thus, polycentricity itself should be considered as a desirable phenomenon. However, some critical remarks were presented 
by Veneri and Burgalassi (2012), especially the ineffectiveness of polycentricity as a tool for social cohesion.

\section{Agglomeration effect of intra-urban location of hotels}

Co-location of hotels results from the process of resource-seeking (Kalnins \& Chung 2004). Co-locating accommodation facilities allows better access to resources like knowledge, technology and human capital (production-based advantages of agglomeration), reduced search costs for hotel guest, proximity to points of hotel guests' interest, and product differentiation (demand-based advantages of agglomeration), easily available in spatial clusters. It is worth mentioning that demand agglomeration effects are mainly generated by business tourism (Luo \& Yang 2016). It must, however, be emphasised, that the weakest and smallest, usually economy and independent, hotels are the main beneficiaries of close proximity to premium, chain-affiliated enterprises (Canina, Enz, \& Harrison 2005; Enz, Canina, \& Liu, 2008). What is interesting, downscale hotels that potentially benefit the most from accommodation clusters, quite often fail to consider agglomeration effects when selecting location (Yang, Wong, \& Wang, 2012). It has also been confirmed that, under some conditions, agglomeration of upscale hotels might also attract enterprises offering upscale accommodation services (Kalnins \& Chung 2004; Urtasun \& Gutiérrez 2017).

A multifunctional urban space does not enable easily identifiable spatial clusters of tourism industry. However, identification of agglomeration effects of particular services, such as accommodation, is much more achievable (Ashworth \& Page 2011). Spatial agglomeration effect has been confirmed as one of most significant factors determining hotel location selection (Kalnins \& Chung 2004). It is argued that hotel spatial clusters reduce the effort, time, and cost for customers seeking accommodation facilities (Adam \& Amuquandoh 2013). At the same time, heterogeneity of services offered by various hotels might significantly reduce direct rivalry between co-located companies and additionally attract demand as hotel guests prefer variety (Kalnins \& Chung 2004).

Balaguer \& Pernías (2013) agreed with the neoclassical assumption concerning location and prices, and argued that the density of closest competitors will negatively affect hotel prices. However, Baum, \& Haveman (1997), and Baum \& Mezias (1992) found that the less similar competitor is, the less similar resources are required, and the more a hotel benefits from co-location, including higher rates, and revenues, and lower organisational failure rate. Moreover, co-locating negatively affects hotel performance when most enterprises in such location represent low-cost strategic orientation (Canina et al. 2005). Thus, economically effective and spatially durable clusters should disable localised competition and include complementary hotels focused on different market segments, representing different price-competition approaches, and not oriented for low-cost strategy (Canina et al. 2005; Urtasun \& Gutiérrez 2006). On the contrary, evidence from Niagara Falls region confirmed that hotel failure rate is negatively influenced by distance to competitors (Ingram \& Inman 1996). It is assumed that the appearance of a new hotel might influence the incumbents to improve their quality of services and, as a consequence, to increase the attractiveness of the whole industry (McCann \& Vroom 2010). This positive agglomeration effects should be emphasised. The differences between the results presented in the above-mentioned research might be influenced by different methodologies of different academic disciplines (Yang, Luo, \& Law 2014) or different levels of urban hotel industry development, including spatial development investigated in this paper.

\section{Intra-urban location of hotel clusters}

Egan \& Nield (2000) introduced an impactful model explaining urban hotel location, based on an assumption that land is a scarce and 
valuable resource. Thus, two factors need to be considered when selecting hotel location: land accessibility and bid-rent. Depending on distance from the city centre, different types of hotels are concentrated in different parts of the city: luxury hotels in the city centre, small-scale budget hotels operating in revitalised buildings at the edge of the centre, business hotels in the suburbs, and midscale budget and business hotels at the edge of the city (Egan \& Nield 2000). Thus, the development of different hotel sectors might enable different spatial clusters of investigated enterprises, depending on their distance from the city centre.

The paradox of coexistence (both symbiosis and incompatibility) of historic city preservation and urban tourism industry development should be underlined. This paradox stimulates two types of locations profitable for accommodation facilities: (1) intermediate zone locations, on the edge between the historic and modern commercial city, and (2) peripheral locations, separated from the heritage of the city, understood as a resource for urban tourism industry (Ashworth 1989). The paradox in question might be strengthened as some tendencies occur. First of all, while urban tourism's contribution to tourism in general is recognised as extremely significant, the role of urban tourism in the development of cities is not so obvious (Ashworth \& Page 2011). Moreover, the development of the above-mentioned intermediate zone locations might be strengthened as revitalisation of former industrial districts in downtown areas occurs (Bégin 2000).

Historic city cores are among the most popular tourist destinations, attracting a significant number of tourists and substantially contributing to tourism consumption (Edwards, Griffin, \& Hayllar 2008). Adam and Amuquandoh $(2013,2014)$ investigated the proximity to the city centre as a determinant of hotel location selection. The authors found that $65.0 \%$ of hoteliers found this factor significant. Thus, city centre is the most impactful place creating hotel spatial clusters. This was confirmed by Napierała and Leśniewska
(2015), Pawlicz and Napierała (2017), Shoval (2006), and Shoval and Cohen-Hattab (2001) who investigated the impact of distance from the city centre, or location in central district of the city, on hotel room rates. The authors used both quantitative and qualitative methods and found that location in a city centre allows hoteliers to offer their services at higher prices. Adam (2013) and Adam and Amuquandoh (2014) confirmed that the higher a hotel is ranked, the more its owners are oriented towards economic opportunities, and the more the city centre becomes a significant and exclusive factor influencing spatial agglomeration. Budget hotels prefer locations in a city periphery. This accommodation facilities are mainly concentrated close to transportation hubs and main roads, as well as some tourist attractions.

Regarding the results of Adam and Amuquandoh $(2013,2014)$ that $99.3 \%$ of hotel owners and managers identified proximity to guests as a significant determinant of hotel location decision, some other places stimulating hotel spatial clusters might occur. Moreover, $41.3 \%$ of hoteliers found that availability of other establishments in a given location they are considering is a significant determinant of hotel location selection. This is in line with findings from Baum and Mezias (1992) research. They found that hotels benefit mainly from being located close to points of tourist interest and from local competitive climate. Thus, the process of hotel location selection must include existing hotel spatial clusters. Other non-economic determinants of hotel co-location were discussed by Shoval (2006) and Yang et al. (2012), including morphology, history of the city, and spatial policy.

Bégin (2000) examined changes of hotel distribution in Chinese city of Xiamen and confirmed decreasing share of the historic core of the city as an area of hotel location. In parallel, new hotel spatial clusters were developed in Xiamen: (1) the transitional zone between old town and new town, favoured by mid-scale hotels, (2) peripherally located new town with significantly developed commercial functions, attracting luxury hotels, 
and (3) transportation nodes, also preferred by luxury hotels. Similar findings were delivered by Oppermann, Din and Amri (1996). The authors identified the focal points of hotel clustering in Kuala Lumpur: (1) historic city centre, (2) new central business district, (3) ethnic neighbourhoods, very specific for Kuala Lumpur, clustering accommodation facilities oriented for sex tourism, and (4) transportation hubs, including road, railway, and airway infrastructure. Harris (1997) underlined a phenomenon of airport clusters developed in suburbs where meeting and accommodation services are dominating. On the contrary, in cities like Hong Kong, where the transport network is extremely developed and transport facilities are widely accessible, transport nodes do not affect hotel location (Li et al. 2015). Additionally, Yang et al. (2012) investigated accommodation facilities in Beijing and confirmed the technology hub as another type of hotel cluster.

\section{Theoretical evolutionary model of polycentric intra-urban development of hotels}

The theoretical model of polycentric intraurban development of hotel facilities is introduced in this research. The assumptions of the model are based on the idea of sinusoidal changes of spatial forces: agglomerative and dispersive (Anas et al. 1998). It is hypothesised that in the first phase of intraurban development of hotel facilities, the largest number of the hotels is concentrated in the most profitable location of the city
- the centre. Agglomerative force is the only substantial factor influencing hotel location selection. New hotel investments are striving for geographic proximity to the existing central core. Thus, the second phase starts. Dispersive force begins to dominate over agglomerative one. The area of concentration of hotel facilities is continuously sprawling. Saturation of urban space with hotel entities should be emphasised, rather than concentration in a central location. Then, the third phase begins. Agglomeration effects begin to dominate. New hotel enterprises oriented for diversity of hotel facilities in particular locations create a new core of spatial concentration. As the hotel industry develops and new hotels are emerging throughout the city, more and more centres of investigated services are formed, and therefore the non-efficient centres disappear.

Selectivity is one of the behavioural characteristics of urban tourism underlined by Ashworth and Page (2011) and Gutiérrez, García-Palomares, Romanillos and SalasOlmedo (2017). It means that tourists are interested only in a small part of the city's offer and, consequently, a small part of urban space. Thus, both mono- and polycentric urban development theories seem to be justified from behavioural perspective. Yang et al. (2014) complained that the main limitation of most polycentric theoretical models of hotel location selection is their inability to provide a practical, detailed information on absolute location within the investigated area, especially when availability of possible hotel locations is not included in the enquiry.

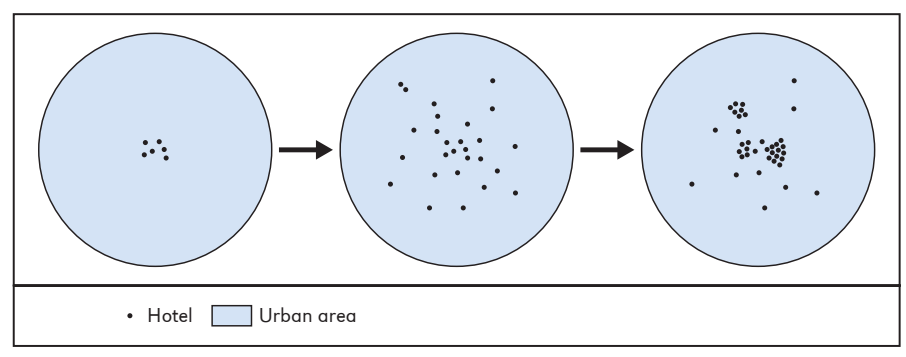

Figure 1. Theoretical evolutionary model of polycentric intra-urban development of hotels 
However, the evolutionary approach for hotel location decisions analysis is suggested when results are expected to be valuable from managerial perspective (Yang, Tang, Luo \& Law 2015).

\section{History of the hotel industry in Budapest}

The three oldest locations of hotel enterprises in Budapest, developed before second world war, should be emphasised: (1) the boulevard along the Danube river in Pest, (2) the Gellert Hill in Buda, and (3) the Margaret Island, oriented towards spa and wellness. During the communist period, three state-owned companies dominated the Hungarian hotel industry: Hungar Hotels, Pannonia Hotels and Danubius Hotels (Matczak \& Napierała 2014).

Bartl (1997) underlined that in the 1980s, in Hungary (as opposed to other socialist countries of East-Central Europe) some economic reforms and political liberalisation started. Thus, most of international direct investments, including brand new locations of international hotel chains, occurred in Hungary, mainly in Budapest. City size is one of the most significant factors influencing competitive advantages of accommodation facilities. Thus, in East-Central Europe, Budapest was and still is considered by hoteliers as one of primary locations (Johnson \& Vanetti 2005a).

After the collapse of communism in EastCentral Europe, Hungarian government changed the goals of tourism policy as the industry became significant for national balance of payments (Johnson \& Vanetti 2005b). However, the transition of Hungarian economy into capitalism was slower than Polish or Czech. Moreover, the political situation of the neighbouring Balkans was destabilised. Thus, in the early 1990s, no significant hotel investments were noticed, except for the opening of a luxury, 5-star Kempinski Hotel Corvinus with 351 rooms in 1992 (Bartl 1997). In 1996, assets located in Budapest, and managed by state-owned company Hungar Hotels were sold to Danubius Hotels, privatised in 1991. The only exception to this acquisition was the Forum Hotel with 400 rooms, sold to Inter-Continental Hotels Corporation (Bartl 1997).

During the 1990s, substantial outflow of population from downtown Budapest started (Timár \& Váradi 2001). As the result of suburbanisation, the economic and social character of the city centre has been changed. The growth of commercial function, including accommodation facilities oriented for tourism purposes, has rapidly started. It was argued that spatial patterns of accommodation facilities development in Budapest significantly affected spatial changes of formal and informal tourism infrastructure both in the city and in the metropolitan area (Michalkó et al. 2017).

Substantial growth of hotel industry in Budapest during the transition period needs to be underlined both in spatial (see Fig. 2) and quantitative (see Tab. 1) context. However, this increase can mainly be contributed to the development of upscale hotels. The number of 4- and 5-star hotels increased from 11 to 106 , and the number of upscale hotel rooms increased from 3,286 to 19,291. This growth was influenced by both brand new investments and the improving quality of midscale hotels. Moreover, since 2013, the number of hotels has stayed more or less constant. But, regarding the growth of luxury market and the permanent decrease of economy hotels, as well as of the midscale market since 2013, the structure of hotels has significantly changed. Nowadays, 4- and 5-star hotels dominate in both the number of hotels (54.4\%), and hotel rooms (75.0\%).

\section{Methodological framework} Data collection

With regard to the evolutionary character of the introduced model, spatial distribution of hotel entities in Budapest during the years 1982, 2004, 2013, and 2018 was compared. Data was collected from travel guides and tourist maps for 1982, and the online databases of: Magyar Turizmus Zrt. (Hungarian 
Table 1. Number of hotels and hotel rooms in Budapest, in the years 1982-2018

\begin{tabular}{|l|c|c|c|c|}
\hline \multicolumn{1}{|c|}{ Type of hotel } & 1982 & 2004 & 2013 & 2018 \\
\hline Luxury hotels & 11 & 50 & 85 & 106 \\
\hline Hotels & 3,286 & 9,229 & 13,302 & 14,476 \\
Hotel rooms & 5 & 95 & 103 & 86 \\
\hline Midscale hotels & 6,639 & 6,045 & 4,713 \\
\hline Hotels & 1,503 & 18 & 9 & 4 \\
Hotel rooms & 12 & 960 & 546 & 102 \\
\hline Economy hotels & 1,349 & 162 & 197 & 195 \\
\hline Hotels & 28 & 16,828 & 19,893 & 19,291 \\
\hline Hotel rooms & 6,138 &
\end{tabular}

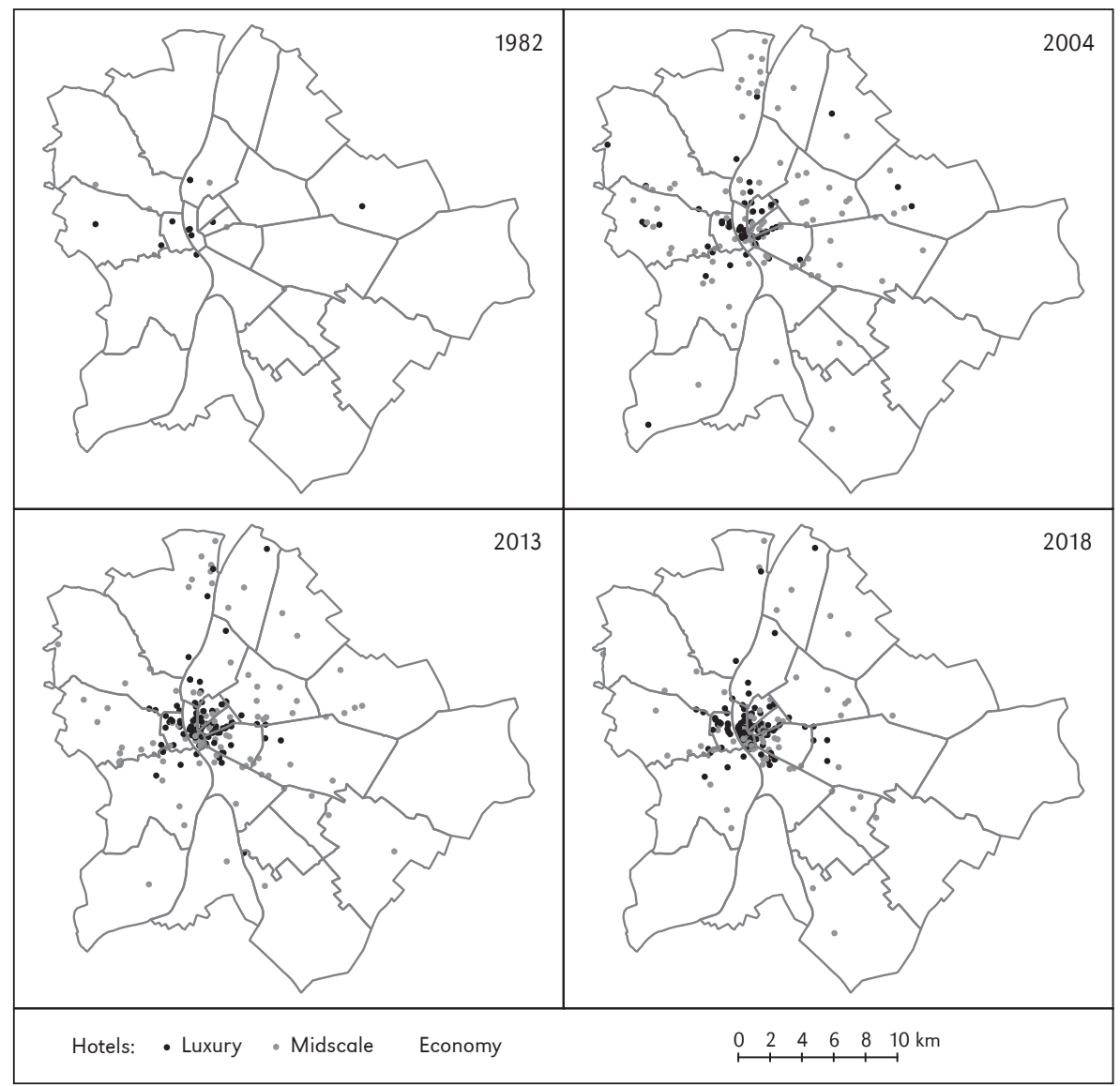

Figure 2. Location of Budapest hotels in the years 1982-2018 
Destination Management and Tourism Marketing Organisation) for 2004, and 2013; MSZÉSZ (Hungarian Association of Hotels and Restaurants), Magyar Turisztikai Ügynökség (Hungarian Tourism Agency), and Booking.com for 2018. The following characteristics of every investigated hotel were recognised: hotel brand, postal address, number of rooms. Additionally, using the Google Maps geocoding feature (Google 2018), postal addresses of investigated hotels were converted into geographical coordinates. For non-existing, historical postal addresses, geographical coordinates were collected manually.

\section{Kernel density estimation}

To identify hotel clusters in Budapest in the years 1982, 2004, 2013, and 2018, weighted kernel density estimation was applied. It is argued that kernel-based estimators are recognized as a geographical methods effective to identify hotspots or delineate core areas of the investigated phenomenon (Majewska, Napierała \& Adamiak 2016; Tjørve, Flognfeldt \& Tjørve 2013). Kernel density estimation is a non-parametric probabilistic technique of geospatial analysis. Standard kernel density function is estimated for each point of $x$ belonging to the data sample of size $n$, based on probability distributions for all $X_{i}$ found within a given radius $h$, shaped by kernel K (Terrell \& Scott 1992; Tjørve et al. 2013):

$$
f(x)=\left[\frac{1}{n h^{2}}\right] \sum_{i=1}^{n} K\left[\frac{x-x_{i}}{h}\right]
$$

Regarding the argumentation of Calenge (2015) Epanechnikov, kernel K was used as more efficient than the most popular bivariate kernel. Smoothing factor $h$ was calculated by least-squares cross-validation, as suggested by Tjørve et al. (2013). Moreover, as the number of rooms was found to be a significant factor describing hotels, weighted kernel density estimation was applied. Hotel locations were weighted by number of hotel rooms. In order to plot the clusters of hotels weighted by hotel rooms heatmap, Quantum GIS 2.18.3 software was applied. Moreover, least-squares cross-validation was run in R software ('adehabitatHR' package) to calculate the smoothing factor.

\section{Empirical results}

Changes of location and development of hotel clusters in Budapest were investigated by maps of weighted kernel density estimation (see Fig. 3). As large, upscale, and branded hotels were recognised as initiating hotel clusters (Helmers, Connor, Florax, \& Vroom 2009), separate spatial analysis was prepared only for luxury accommodation facilities (see Fig. 4).

It needs to be underlined that during the investigated period, clustering of hotels occurred only in the central districts of Budapest. At the end of the communist period, no clear local clusters of hotels in Budapest were identified. However, hotels were generally located in few historical districts of Pest: V, VI, VII, and VIII. On the one hand, upscale hotels slightly preferred locations along the Danube Promenade, while on the other, budget hotels selected locations along the Rákóczi street. At the beginning of the 2000s, spatial distribution of hotels covered a much larger part of the city. This confirms the theoretical assumption about dispersive forces. Then, at the beginning of 2010s, location decisions of hotels started to be oriented towards agglomeration effects.

Before 2018, few local clusters were formed: (1) the area between the Danube Promenade and the Vörösmarty square, (2) the zone along the Váci street (famous promenade), (3) the area around the Kálvin square (one of the main city transportation hubs), (4) the zone between two parallel streets of Andrássy and Király, and (5) the area along the Rákóczi street. It is worth mentioning, that the first three hotel clusters mentioned above are located inside or on the border of district $\mathrm{V}$, named Belváros-Lipótváros. This is the historical core of the Hungarian 


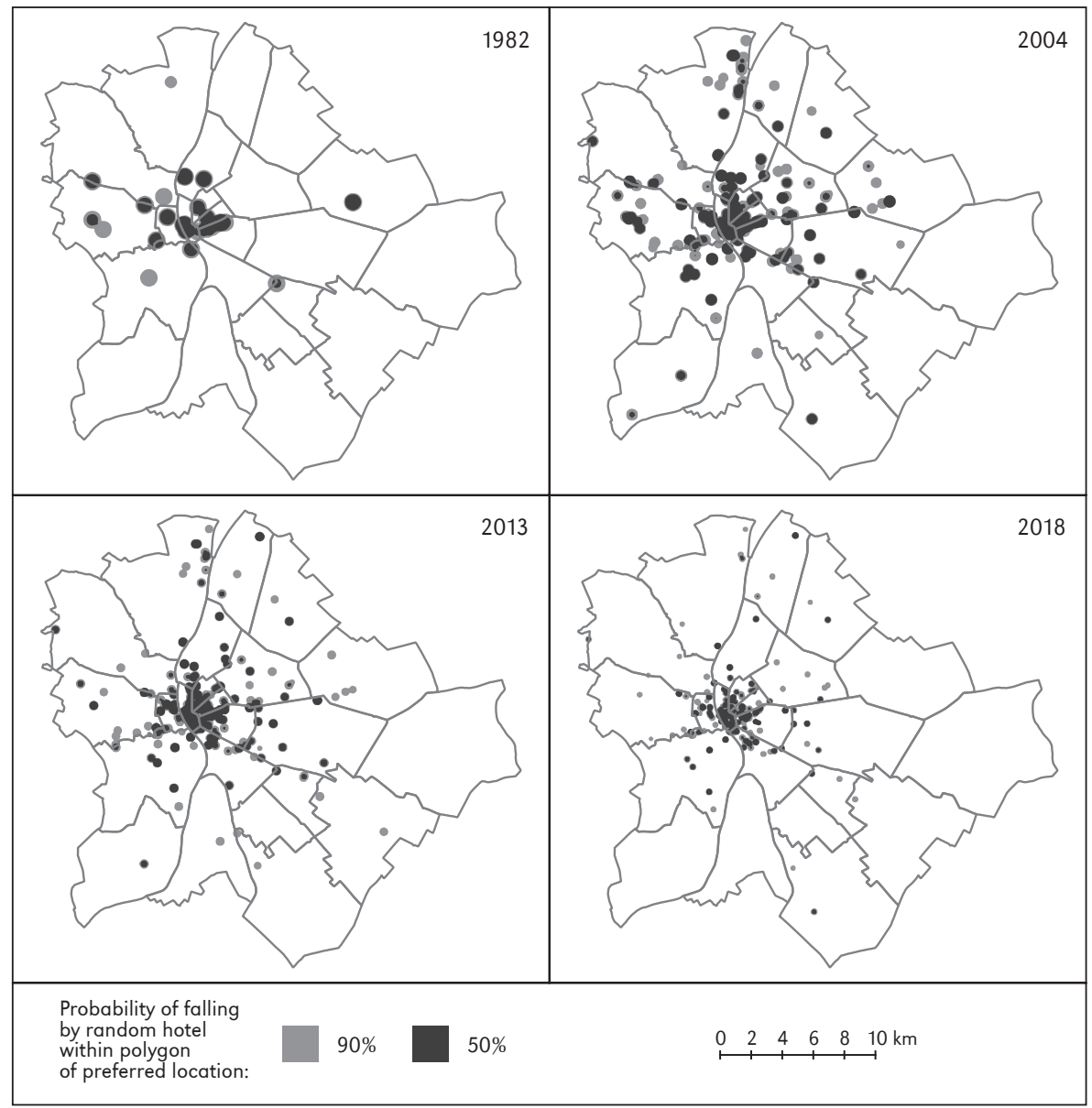

Figure 3. Kernel density of all Budapest hotels weighted by number of hotel rooms, in the years 19822018

capital where the political, administrative, financial, commercial, and tourist functions are concentrated. Moreover, all of these hotel clusters were initiated by upscale hotels (see Fig. 4). Interestingly, the spatial range of these hotel clusters has become significantly smaller. It is confirmed by the decreasing value of smoothing factor $h$ calculated by least-squares cross-validation for investigated years: from 873 metres in 1982, to 297 metres in 2018. Moreover, during the last years, Margaret Island, where hotels mainly offering spa and wellness services used to be located, has lost its clustering function.
It need to be underlined that evolution of hotel clusters was limited to the central districts of Budapest as the process started during the socialist period in $V$ district Belváros-Lipótváros, recognized as the core area of tourism development in Budapest (Dumbrovská \& Fialová 2014). When discussing evolution of hotel clustering in Budapest during the economic transition, the increase of significance of other centrally located historical districts (like VI Terézváros, VII Erzsébetváros, and north part of VIII Józsefváros) should be emphasized. This is in line with findings of Adam \& Amuquandoh (2013, 2014) who confirmed that the proximity to the city 


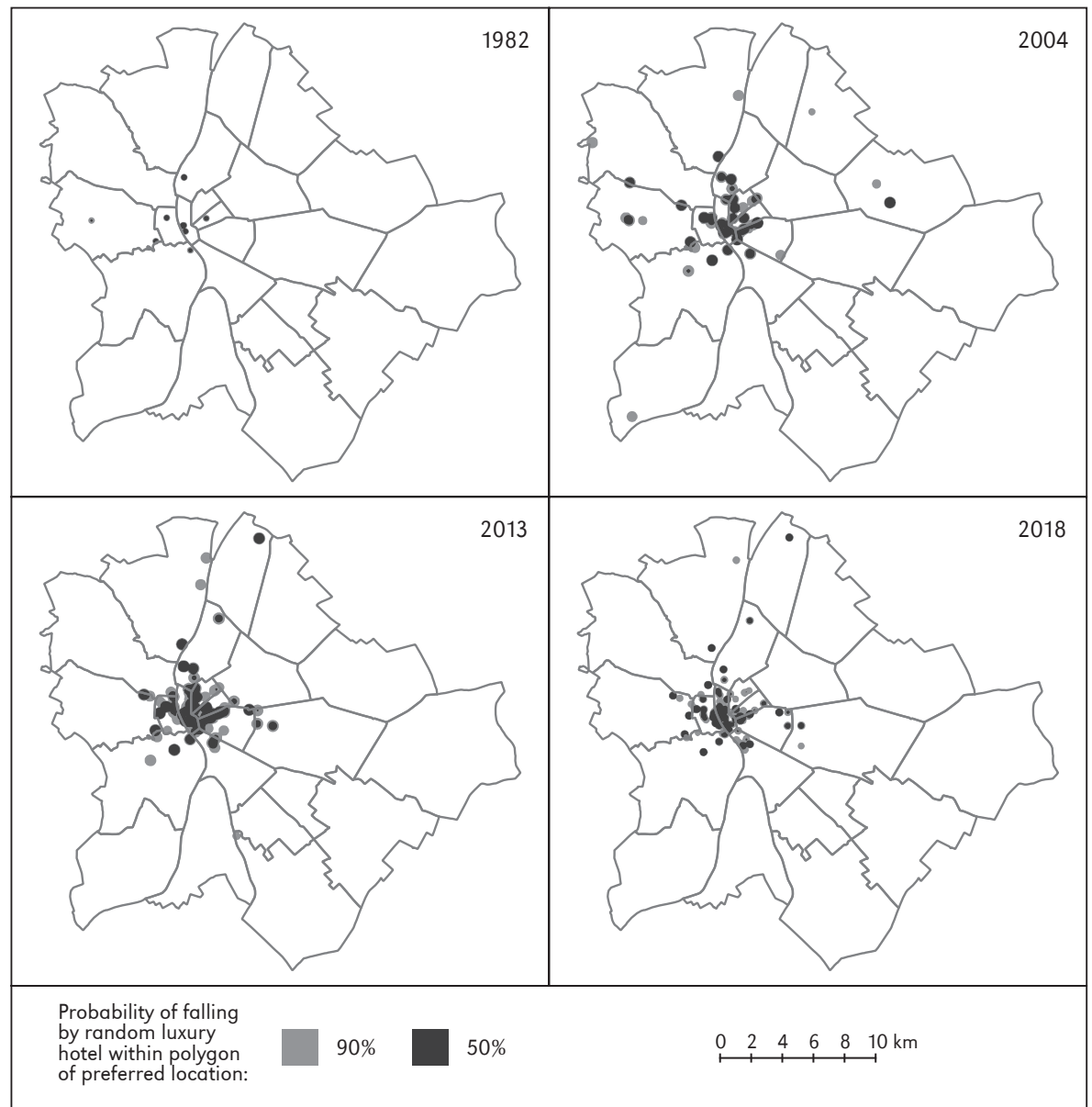

Figure 4. Kernel density of luxury Budapest hotels weighted by number of hotel rooms, in the years 1982-2018

centre is a most substantial determinant of hotel location selection. Thus, during the investigated period between 1982 and 2018, all significant hotel clusters occurred in central districts of Budapest.

\section{Discussion and conclusions}

It is worth stressing that all significant hotel clusters have been developed in central districts of Budapest. Thus, the theoretical model of polycentric intra-urban development of hotel locations proposed in this paper was confirmed only for the central areas of the city. This is in line with the results of Adam
(2013), who confirmed that spatial agglomeration effects of hotels may be observed in $4 \mathrm{~km}$ radius from the central point of the city centre. However, no evidence was found for other places stimulating hotel spatial clusters. As long as the old city centre retains its functions as both the focal area of tourist interest and a retail centre, it might attract hotel investments more than other zones in the city (Dökmeci \& Balta 1999). However, as negative influence of hotel infrastructure on urban space was found in previous studies (e.g. overloading of municipal infrastructure, congestion, pollution, and noise), shifting locations of large hotels from the city 
centre to the suburbs as the goal of urban spatial policy is recommended (Arbel \& Pizam 1977).

Substantial growth of upscale hotels in Budapest, mainly in its central districts, was confirmed by this research. From the beginning of the 19th century, urban areas of concentration of hotel facilities, mainly upscale, so-called grand hotels, were recognised as a morphological emanation of economic and cultural development, significantly affecting urban landscape (Shoval \& CohenHattab 2001; McNeill 2008; Włodarczyk 2011). Moreover, upscale and chain-affiliated hotels substantially contribute to demand agglomeration benefits for the hotel sector (Tsang \& Yip 2009), and attract foreign direct investments of other industries ( Wu 2000). Thus, introducing luxury hotel investments into an urban space might prove a significant tool for urban policy goals like revitalisation, development of post-industrial economy of business conventions and multinational interaction, or even cosmopolitan urbanity (McNeill 2008).

Hotel clusters in Budapest are mainly stimulated by large, upscale hotels. It has been argued by other researchers that decisions, including location selection, are differentiated by the size and ownership of the hotel. Chain-affiliated and larger hotel establishments are expected to be managed in the most professional manner. This is related to company-owned, rather than franchised, hotels (Helmers et al. 2009). Chain-affiliated companies benefit substantially from economies of scale and better access to resources, both local and global. Hotels affiliated by chains, especially large and international ones, are much more resistant to the risk of failure (Ingram \& Baum 1997). Thus, the decisions of large, affiliated hoteliers seem to be most effective. In consequence, small and independent accommodation facilities prefer to follow the locations of more experienced enterprises. Finally, small and independent hotels usually benefit the most from agglomeration effects. These findings constituted foundation for hoteliers' location decisions based on estimated agglomeration effect. Moreover, it might increase the quality of hotel strategic planning. On the other hand, understanding how hotels change their location policy in intra-urban context might positively affect the effectiveness of city planning practice.

It must be emphasised that every spatial model of the city, employing map for visualising purposes, seems to be a very useful, reader-friendly, understandable tool of scientific explanation. However, limitation like reducing real complexity of urban space needs to be underlined (Harris 1997). Juhász-Dóra (2017) explained that hotel location should be considered not only as geographic coordinates, but also as a local embeddedness in the economic, social, cultural, and environmental resources of hotel competitive advantage. Moreover, local relations between competing hotel enterprises should not be understood as an Euclidean proximity. The geographic focus should also include a network approach (Niewiadomski 2013). This understanding of location is crucial for both local and global enterprises and determines the main limitation of this study. The broader geographical context should constitute theoretical framework for further research. However, the contribution of proposed and evidenced theoretical model of polycentric intra-urban development of hotel locations should be emphasized. Development of hotel clusters in the central districts of Budapest, initiated by upscale, large, and chain-affiliated entities was diagnosed. Hence, theoretical concept of polycentricity was partially confirmed, as it explains hotel location selection in central areas of the city only.

\section{Editors' note:}

Unless otherwise stated, the sources of tables and figures are the authors', on the basis of their own research. 


\section{References}

Adam I., 2013. Urban hotel development patterns in the Kumasi Metropolis, Ghana. Tourism Planning \& Development, vol. 10, no. 1, pp. 85-98. https://doi.org/10.1080/21568316.2012.724706

Adam I., Amuquandoh F.E., 2013. Dimensions of hotel location in the Kumasi Metropolis, Ghana. Tourism Management Perspectives, vol. 8, pp. 1-8. https://doi.org/10.1016/j.tmp.2013.05.003

Adam I., Amuquandoh F.E., 2014. Hotel characteristics and location decisions in Kumasi Metropolis, Ghana. Tourism Geographies, vol. 16, no. 4, pp. 653-668. https://doi.org/10.1080/14616688.2012.762689

Adam I., Mensah E.A., 2013. Perceived spatial agglomeration effects and hotel location choice. Anatolia - An International Journal of Tourism and Hispitality Research, vol. 25, no. 1, pp. 49-60. https://doi.org/10.1080/13032917.2013.822818

Anas A., Arnott R., Small K.A., 1998. Urban spatial structure. Journal of Economic Literature, vol. 36, no. 3, pp. 1426-1464.

Arbel A., Pizam A., 1977. Some determinants of urban hotel location: The tourists' inclinations. Journal of Travel Research, vol. 15, no. 3, pp. 18-22.

Ashworth G.J., 1989. Accommodation and the historic city. Built Environment, vol. 15, no. 2, pp. 92-100. Retrieved from http://www.jstor.org/stable/23286293

Ashworth G.J., Page S.J., 2011. Urban tourism research: Recent progress and current paradoxes. Tourism Management, vol. 32, no. 1, no. 1-15. https://doi.org/10.1016/j.tourman.2010.02.002

Balaguer J., Pernías J.C., 2013. Relationship between spatial agglomeration and hotel prices: Evidence from business and tourism consumers. Tourism Management, vol. 36, pp. 391-400. https://doi.org/10.1016/j.tourman.2012.10.004

Bartl H., 1997. The hotel market in the former Eastern Bloc: An overview. Journal of Vacation Marketing, vol. 3, no. 4, pp. 343-353.

Baum J.A.C., Haveman H.A., 1997. Love thy neighbor? Differentiation and agglomeration in the Manhattan hotel industry, 1898-1990. Administrative Science Quarterly, vol. 42, pp. 304-338. https://doi.org/10.2307/2393922

Baum J.A.C., Mezias S.J., 1992. Localized competition and organizational failure in the Manhattan hotel industry, 1898-1990. Administrative Science Quarterly, vol. 37, no. 4, pp. 580-604. https://doi.org/10.2307/2393473

Bégin S., 2000. The geography of a tourist business: Hotel distribution and urban development in Xiamen, China. Tourism Geographies, vol. 2, no. 4, pp. 448-471. https://doi.org/10.1080/146166800750035530

Burger M.J., van der Knaap B., Wall R. S., 2014. Polycentricity and the multiplexity of urban networks. European Planning Studies, vol. 22, no. 4, pp. 816-840. https://doi.org/10.1080/09654313.2013.771619

Calenge C., 2015. Home range estimation in $R$ : The adehabitatHR Package. Office national de la classe et de la faune sauvage: Saint Benoist, Auffargis, France. Retrieved from https://cran.r-project.org/web/packages/adehabitatHR/vignettes/adehabitatHR.pdf [20 August 2019].

Canina L., Enz C.A., Harrison J.S., 2005. Agglomeration efects and strategic orientations: Evidence from the U.S. lodging industry. Academy of Management Journal, vol. 48, no. 4, pp. 565-581. https://doi.org/10.5465/amj.2005.17843938

Dabinett G., Richardson T., 2005. The Europeanization of spatial strategy: Shaping regions and spatial justice through governmental ideas. International Planning Studies, vol. 10, no. 3-4, pp. 201-218. https://doi.org/10.1080/13563470500378549

Dökmeci V., Balta N., 1999. The evolution and distribution of hotels in Istanbul. European Planning Studies, vol 7, no. 1, pp. 99-109. https://doi.org/10.1080/09654319908720504

Dumbrovská V., Fialová D., 2014. Tourist intensity in capital cities in Central Europe: Comparative analysis of tourism in Prague, Vienna and Budapest. Czech Journal of Tourism, vol. 3, no. 1, pp. 5-26. https://doi.org/10.2478/cjot-2014-0001

Edwards D., Griffin T., Hayllar B., 2008. Urban tourism research: Developing an Agenda. Annals of Tourism Research, vol. 35, no. 4, pp. 1032-1052. https://doi.org/10.1016/j.annals.2008.09.002 
Egan D.J., Nield K., 2000. Towards a theory of intraurban hotel location. Urban Studies, vol. 37, no. 3, pp. 611-621. https://doi.org/10.1080/0042098002140

Enz C.A., Canina L., Liu Z., 2008. Competitive dynamics and pricing behavior in US hotels: The role of Co-location. Scandinavian Journal of Hospitality and Tourism, vol. 8, no. 3, pp. 230-250. https://doi.org/10.1080/15022250802305303

Google, 2018. Geocoding API. Retrieved from https://developers.google.com/maps/documentation/geocoding/intro [8 August 2018].

Gutiérrez J., García-Palomares J.C., Romanillos G., Salas-Olmedo M.H., 2017. The eruption of Airbnb in tourist cities: Comparing spatial patterns of hotels and peer-to-peer accommodation in Barcelona. Tourism Management, vol. 62, pp. 278-291. https://doi.org/10.1016/j.tourman.2017.05.003

Harris C.D., 1997. 'The nature of cities' and urban geography in the last half century. Urban Geography, vol. 18, no. 1, pp. 15-35. https://doi.org/10.2747/0272-3638.18.1.15

Helmers C.G., Connor J.M., Florax R.J.G.M., Vroom G., 2009. Entry size, ownership form, and spatial location: An analysis of the hotel industry. Agricultural \& Applied Economics Association, 2009 Joint Annual Meeting, Milwaukee. https://doi.org/10.22004/ag.econ.49561

Ingram P., Baum J.A.C., 1997. Chain affiliation and the failure of Manhattan hotels, 1898-1980. Administrative Science Quarterly, vol. 42, no. 1, pp. 68-102. https://doi.org/10.2307/2393809

Ingram P., Inman C., 1996. Institutions, intergroup competition, and the evolution of hotel populations around niagara falls. Administrative Science Quarterly, vol. 41, no. 4, pp. 629-658. https://doi.org/10.2307/2393870

Johnson C., Vanetti M., 2005a. Locational strategies of international hotel chains. Annals of Tourism Research, vol. 32, no. 4, pp. 1077-1099. https://doi.org/10.1016/j.annals.2005.03.003

Johnson C., Vanetti M., 2005b. Market developments in the hotel sector in Eastern Central Europe. Advances in Hospitality and Leisure, vol. 1, pp. 153-175. https://doi.org/10.1016/S1745-3542(04)01010-0

Juhász-Dóra K., 2017. Analysis of additional hotel services in the international luxury hotels - a casestudy from Budapest. Proceedings of the 11th International Conference on Business Excellence, vol. 11, no. 1, pp. 884-892. https://doi.org/10.1515/picbe-2017-0094

Kalnins A., Chung W., 2004. Resource-seeking agglomeration: A study of -market entry in the lodging industry. Strategic Management Journal, vol. 25, no. 7, pp. 689-699. https://doi.org/10.1002/smj.403

Li M., Fang L., Huang X., Goh C., 2015. A spatial-temporal analysis of hotels in urban tourism destination. International Journal of Hospitality Management, vol. 45, pp. 34-43. https://doi.org/10.1016/j.ijhm.2014.11.005

Luo H., Yang Y., 2016. Intra-metropolitan location choice of star-rated and non-rated budget hotels: The role of agglomeration economies. International Journal of Hospitality Management, vol. 59, pp. 72-83. https://doi.org/10.1016/j.ijhm.2016.09.007

Majewska J., Napierała T., Adamiak M., 2016. Wykorzystanie nowych technologii i informacji do opisu przestrzeni turystycznej. Folia Turistica, vol. 41, pp. 309-339.

Matczak A., Napierała T., 2014. Zmiany w lokalizacji hoteli w Budapeszcie [in:] G. Gołembski, A. Niezgoda (eds.), Turystyka wobec zmian współczesnego świata. Zmiany, bariery, innowacje, Poznań: Wydawnictwo Uniwersytetu Ekonomicznego w Poznaniu, pp. 127-139.

McCann B.T., Vroom G., 2010. Pricing responde to entry and agglomeration effects. Strategic Management Journal, vol. 31, pp. 284-305. https://doi.org/10.1002/smj.805

McNeill D., 2008. The hotel and the city. Progress in Human Geography, vol. 32, no. 3, pp. 383-398. https://doi.org/10.1177/0309132508089096

Michalkó G., Balizs D., Kiss É., Faragóné Huszár S., Sik A., Karácsonyi D., 2017. A vidékiesség vonzásában: a nagyvárosi agglomerációk láthatatlan turizmusa Magyarországon. Tér És Társadalom, vol. 31, no. 3, pp. 44-60. https://doi.org/10.17649/TET.31.3.2853

Napierała T., Leśniewska K., 2015. Location-based determinants of accommodation prices [in:] M. Kozak, N. Kozak (eds.), Tourism Economics, Newcastle upon Tyne: Cambridge Scholars Publishing, pp. 124-139.

Niewiadomski P., 2013. Towards an economic-geographical approach to the globalisation of the hotel industry. Tourism Geographies: An International Journal of Tourism Space, Place and Environment, vol. 16, no. 1, pp. 48-67. https://doi.org/10.1080/14616688.2013.867528 
Oppermann M., Din K.H., Amri S.Z., 1996. Urban hotel location and evolution in a developing country: The case of Kuala Lumpur, Malaysia. Tourism Recreation Research, vol. 21, no. 1, pp. 55-63. https://doi.org/10.1080/02508281.1996.11014763

Parr J.B., 2004. The polycentric urban region: A closer inspection. Regional Studies, vol. 38, no. 3, pp. 231240. https://doi.org/10.1080/003434042000211114

Pawlicz A., Napierała T., 2017. The determinants of hotel room rates: An analysis of the hotel industry in Warsaw, Poland. International Journal of Contemporary Hospitality Management, vol. 29, no. 1, pp. 571-588. https://doi.org/10.1108/IJCHM-12-2015-0694

Shoval N., 2006. The geography of hotels in cities: An empirical validation of a forgotten model. Tourism Geographies: An International Journal of Tourism Space, Place and Environment, vol. 8, no. 1, pp. 56-75. https://doi.org/10.1080/14616680500392499

Shoval N., Cohen-Hattab K., 2001. Urban hotel development patterns in the face of political shifts. Annals of Tourism Research, vol. 28, no. 4, pp. 908-925. https://doi.org/10.1016/50160-7383(00)00083-9

Terrell G.R., Scott D.W., 1992. Variable kernel density estimation. The Annals of Statistics, vol. 20, no. 3, pp. 1236-1265.

Timár J., Váradi M.M., 2001. The uneven development of suburbanization during transition in Hungary. European Urban and Regional Studies, vol. 8, no. 4, pp. 349-360. https://doi.org/10.1177/096977640100800407

Tjørve E., Flognfeldt T., Tjørve K.M.C., 2013. The effects of distance and belonging on second-home markets. Tourism Geographies: An International Journal of Tourism Space, Place and Environment, vol. 15, no. 2, pp. 268-291. https://doi.org/10.1080/14616688.2012.726264

Tsang E.W.K., Yip P.S.L., 2009. Competition, agglomeration, and performance of Beijing hotels. Service Industries Journal, vol. 29, no. 2, pp. 155-171. https://doi.org/10.1080/02642060802294896

Urtasun A., Gutiérrez I., 2006. Hotel location in tourism cities: Madrid 1936-1998. Annals of Tourism Research, vol. 33, no. 2, pp. 382-402. https://doi.org/10.1016/j.annals.2005.12.008

Urtasun A., Gutiérrez I., 2017. Clustering benefits for upscale urban hotels. International Journal of Contemporary Hospitality Management, vol. 29, no. 5, pp. 1426-1446.

https://doi.org/10.1108/IJCHM-10-2015-0583

Veneri P., Burgalassi D., 2012. Questioning polycentric development and its effects. Issues of definition and measurement for the Italian NUTS-2 regions. European Planning Studies, vol. 20, no. 6, pp. 10171037. https://doi.org/10.1080/09654313.2012.673566

Włodarczyk B., 2011. The tourism landscape and tourist space of the city. Folia Turistica, vol. 25, no. 1, pp. 265-282.

Wu F., 2000. Modelling intrametropolitan location of foreign investment firms in a Chinese city. Urban Studies, vol. 37, no. 13, pp. 2441-2464. https://doi.org/10.1080/00420980020005415

Yang Y., Luo H., Law R., 2014. Theoretical, empirical, and operational models in hotel location research. International Journal of Hospitality Management, vol. 36, pp. 209-220.

https://doi.org/10.1016/j.ijhm.2013.09.004

Yang Y., Tang J., Luo H., Law R., 2015. Hotel location evaluation: A combination of machine learning tools and web GIS. International Journal of Hospitality Management, vol. 47, pp. 14-24.

https://doi.org/10.1016/j.ijhm.2015.02.008

Yang Y., Wong K.K.F., Wang T., 2012. How do hotels choose their location? Evidence from hotels in Beijing. International Journal of Hospitality Management, vol. 31, no. 3, pp. 675-685. https://doi.org/10.1016/j.ijhm.2011.09.003

Yue W., Liu Y., Fan P., 2010. Polycentric urban development: The case of Hangzhou. Environment and Planning, vol. 42, no. 3, pp. 563-578. https://doi.org/10.1068/a42116 